\title{
5-Ethyl-2'-Deoxyuridine. Cytotoxicity and DNA Incorporation Demonstrated with Human Leukemic Cells and PHA-Stimulated Lymphocytes in vitro
}

\author{
HANNU TUOMINEN, ${ }^{a}$ DONALD BERGSTROM ${ }^{\mathrm{b}}$ and JUHANI A. VILPO ${ }^{\mathrm{a}, *}$ \\ a Department of Clinical Chemistry, Laboratory of Molecular Hematology, University of \\ Oulu, SF-90220 Oulu, Finland and ${ }^{\text {b }}$ Department of Chemistry, University of North \\ Dakota, North Dakota 58202
}

5-Ethyl-2' -deoxyuridine (5EtdUrd) is a biologically active thymidine analogue. The cytotoxicity of 5EtdUrd was investigated with seven established human leukemia cell lines as well as with human peripheral blood PHA-stimulated lymphocytes. All types of leukemia cells were susceptible to the toxicity of $5 E t d U r d$ as assayed with a $\left[\mathrm{U}-{ }^{14} \mathrm{C}\right]-\mathrm{L}$-leucine incorporation system developed for this study. A $50 \%$ inhibition of leucine incorporation in 3-day cultures was induced by 1.3-3.8 $\mu \mathrm{M}$ 5EtdUrd with leukemic cells, but the concentration required to induce similar inhibition with PHA-stimulated lymphocytes was approximately 100-fold. The toxicity of 5EtdUrd seemed to require active DNA synthesis, since the inhibition of leucine incorporation became obvious only after the first 24 hours of culture.

The DNA incorporation studies were based on a new isotopically labeled 5EtdUrd derivative, $\left[2-{ }^{14} \mathrm{C}\right] 5 \mathrm{E} t d \mathrm{U} d$, synthesized for this study in our laboratory. It was demonstrated for the first time that most of the radioactivity derived from $\left[2-{ }^{14} \mathrm{C}\right] 5 \mathrm{E} t d U r d$ in DNA was in 5-ethyluracil.

5EtdUrd has a powerful antileukemic potency in vitro. Its effects against human leukemia in vivo remain to be tested.

5-Ethyl-2'-deoxyuridine (5EtdUrd) is a biologically active compound which readily incorporates into viral ${ }^{1-3}$ (see also Ref. 4), bacterial, ${ }^{5}$ and mammalian cell DNA. ${ }^{6-8}$ The compound inhibits in vitro proliferation of the above-mentioned organisms and cells with the exception of human fibroblasts. ${ }^{6}$ In preliminary work we have observed that 5 EtdUrd exerts powerful antileukemic toxicity in vitro. ${ }^{9}$ In this paper we report the results of cytotoxicity tests performed with 5EtdUrd against seven selected human leukemic cell lines as well as against normal human peripheral blood PHA-stimulated lymphocytes. We describe here a new synthesis method for $\left[2-{ }^{14} \mathrm{C}\right] 5 \mathrm{EtdUrd}$ and show that 5 EtdUrd is readily incorporated into the DNA of malignant and benign hematopoietic cells as 5-ethyluracil, although considerable differences in cytotoxicities between normal and malignant lymphocytes were observed.

* To whom correspondence should be addressed. 


\section{MATERIALS AND METHODS}

Materials. RPMI 1640 culture medium, fetal calf serum, L-glutamine, penicillin and streptomycin were obtained from Gibco Ltd. (Middlesex, England); Hoechst Compound 33258 was from Calbiochem-Behring Corp. (La Jolla, California); phytohemagglutinin was from Difco (Detroit, Michigan); proteinase K was from Sigma Chemical Co. (St. Louis, Missouri); bases and nucleosides were from Calbiochem-Behring Corp. and from Sigma Chemical Co.; Insta-Gel II scintillation liquid was from Packard Instrument Company Inc. (Dovers Grove, Illinois).

Synthesis of $\left[2-{ }^{14} \mathrm{C}\right] 5$-Ethyl-2'-deoxyuridine. The synthesis was performed (D.E.B.) as follows: In a $10 \mathrm{ml}$ pear-shaped flask fitted with a magnetic stirring bar, a reflux condensor and a nitrogen line bypass, were combined $2.8 \mathrm{mg} 2^{\prime}$-deoxyuridine $(0.012 \mathrm{mmol})$, mercury(II)-acetate $(7.5 \mathrm{mg}, 0.0235 \mathrm{mmol}),\left[2-{ }^{14} \mathrm{C}\right]-2^{\prime}$-deoxyuridine $(1.73 \mathrm{MBq}$, specific activity $2150 \mathrm{MBq} / \mathrm{mmol}, 0.184 \mathrm{mg}$; The Radiochemical Centre, Amersham, England), and distilled water $(1.20 \mathrm{ml})$. The mixture was heated at $50{ }^{\circ} \mathrm{C}$ for $12 \mathrm{~h}$. The cooled reaction mixture was lyophilized, a solution of $0.1 \mathrm{M} \mathrm{Li}_{2} \mathrm{PdCl}_{4}$ in methanol added (260 $\mu \mathrm{l}, 0.026$ $\mathrm{mmol}$ ), and the mixture diluted to $1 \mathrm{ml}$ with methanol. The flask was fixed with plasticine clay onto the bottom of a $500 \mathrm{ml}$ Parr bottle and stirred magnetically under an ethene atmosphere $(62 \mathrm{kPa})$ for $12 \mathrm{~h}$ using an apparatus similar to that described by Barefield. ${ }^{10}$ The flask was evacuated via a water aspirator, $6.8 \mathrm{mg} 10 \% \mathrm{Pd} / \mathrm{C}$ suspended in $0.5 \mathrm{ml}$ methanol added, and the apparatus pressurized with hydrogen $(76 \mathrm{kPa})$. After $12 \mathrm{~h}$ the reaction mixture showed a single spot on TLC (silica gel G-60, $10 \%$ methanol/CHCl ${ }_{3}$ ) at $R_{\mathrm{f}}$ 0.25 , corresponding to 5 EtdUrd. ${ }^{11}$

The whole methanol solution was streaked onto a $20 \times 20 \mathrm{~cm}$ silica gel G-60 plate and eluted with $15 \%$ methanol/ $\mathrm{CHCl}_{3}$. The UV absorbing band containing the 5EtdUrd was scraped off and the silica gel washed with a total of $15 \mathrm{ml}$ methanol. Evaporation of the methanol gave a solid, which was then dissolved in $1.0 \mathrm{ml}$ distilled water and centrifuged at $15000 \mathrm{rpm}$. Lyophilization of the supernatant gave the product as an off-white solid, which by TLC analysis was pure 5 EtdUrd. From analysis of a small aliquot, $0.334 \times 10^{8} \mathrm{dpm}$ were counted, which corresponds to $555 \mathrm{kBq}$ and an overall yield of $32 \%$. The specific activity was $130 \mathrm{MBq} / \mathrm{mmol}$.

Cells. The human leukemic cell lines were a generous gift from Professor Leif Andersson, Department of Pathology, University of Helsinki. The main characteristics of the cell lines were as follows: BALL- 1 is an acute lymphoblastic leukemia with B cell differentiation. ${ }^{12} \mathrm{HL}-60$ is an acute promyelocytic leukemia line. ${ }^{13} \mathrm{JM}$ is an acute T cell leukemia line. ${ }^{14} \mathrm{~K}-562$ is derived from a case of chronic granulocytic leukemia in blast crisis. ${ }^{15}$ This line has a Philadelphia chromosome and it possesses erythroid and myeloid features. NALL-1 is an acute lymphoblastic leukemia cell line with neither B nor T cell differentiation. ${ }^{12}$ Raji represents a cell line derived from Burkitt's lymphoma. ${ }^{16}$ U-937 is a histiocytic lymphoma cell line. ${ }^{17}$ Human peripheral blood lymphocytes were isolated from healthy donors by density gradient centrifugation. ${ }^{18}$

The leukemia cells were maintained in $260 \mathrm{ml}$ culture flasks (A/S Nunc, Roskilde, Denmark) in RPMI 1640 supplemented with $10 \%$ fetal calf serum (20\% with HL-60), 2 $\mathrm{mM}$ L-glutamine, $100 \mathrm{U}$ penicillin per $\mathrm{ml}$, and $100 \mu \mathrm{g}$ streptomycin per ml. In maintaining cultures new medium was added twice a week. The cultures did not contain Mycoplasm at the detection level reached by staining with Hoechst Compound $33258 .{ }^{19}$ Peripheral blood lymphocytes were grown in similar conditions in the presence of phytohemagglutinin ( 7 $\mu \mathrm{g} / \mathrm{ml})$. 
Cytotoxicity tests. All assays were performed on Cooke Microtiter V plates (Sterilin Ltd., Middlesex, England). The tests were performed under optimal growth conditions as described in detail elsewhere. ${ }^{20}$ The given amount of 5EtdUrd was placed in the culture wells together with $200 \mu \mathrm{l}$ of cell suspension containing $2 \times 10^{4}$ leukemic cells or $10^{5}$ peripheral blood mononuclear cells. The cells were allowed to proliferate for $68-74 \mathrm{~h}$ at $37^{\circ} \mathrm{C}$ in a humidified, $\mathrm{CO}_{2}$-controlled $(5 \%)$ atmosphere. At the end of the incubation, living cells were counted using their ability to exclude trypan blue stain in a hemocytometer, ${ }^{21}$ or the cells were exposed for the four final hours to $0.74 \mathrm{kBq}$ of [U- $\left.{ }^{14} \mathrm{C}\right]-\mathrm{L}$-leucine (specific activity $96 \mathrm{MBq} / \mathrm{mmol}$ ) and harvested by a multiple cell harvester (Cell Harvester D-001, Flow Labratories Ltd., U.K.). Firstly, macromolecules were precipitated by adding $8 \mu \mathrm{l}$ of $5 \mathrm{M}$ perchloric acid to each culture well. The microplates were incubated for $15 \mathrm{~min}$ in an ice-bath. The contents of the microplate wells were collected on glass fiber filter (Titertek Cell Harvester Filters, Flow Laboratories) and rinsed for $40 \mathrm{~s}$ with $0.2 \mathrm{M}$ perchloric acid. Radioactivities were measured in a scintillation spectrophotometer (LKB-Wallac 81000 ) with a counting efficiency of approximately $50 \%$.

Incorporation studies. The incorporation studies were performed by exposing human PHA-stimulated lymphocytes for one $h$ or BALL-1 and Raji cells for $72 \mathrm{~h}$ to radioactive $5 E t d U r d$. Individual cellular fractions were collected making use of a modified SchmidtThannhauser method as follows: the cells were first washed with PBS (phosphate-buffered saline, $\mathrm{pH}$ 7.4). They were then dissolved in $666 \mu \mathrm{l}$ of water containing $150 \mu \mathrm{g}$ of highly polymerized carrier DNA. The tubes were incubated in an ice-bath and $333 \mu \mathrm{l}$ of $0.6 \mathrm{M}$ perchloric acid were added. Nucleic acids and proteins were precipitated for $15 \mathrm{~min}$ and the supernatant was taken as an acid-soluble fraction after centrifugation $(10000 \times \mathrm{g}, 2 \mathrm{~min})$. The precipitates were washed once with $1 \mathrm{ml}$ of $0.2 \mathrm{M}$ perchloric acid. They were then dissolved in $0.5 \mathrm{ml}$ of $0.3 \mathrm{M} \mathrm{KOH}$ and RNA was hydrolyzed for $60 \mathrm{~min}$ at $37^{\circ} \mathrm{C} .^{22}$ The hydrolysate was acidified by adding perchloric acid to a final concentration of $0.2 \mathrm{M}$, and DNA and protein were precipitated, dissolved in $20 \mu \mathrm{l}$ of $1 \mathrm{M} \mathrm{NaOH}$ and $1 \mathrm{ml}$ of water. The DNA-containing fraction was isolated by hydrolysis with $1 \mathrm{M}$ perchloric acid at $80^{\circ} \mathrm{C}$. This treatment was repeated. The radioactivity in the various cellular compartments was counted in a scintillation spectrophotometer.

The analysis of radioactivity of individual bases of DNA in human PHA-stimulated lymphocytes and $\mathrm{JM}$ cells was performed after exposure to $\left[2-{ }^{14} \mathrm{C}\right] 5 \mathrm{EtdU}$ rd as follows: human PHA-stimulated lymphocytes were concentrated by centrifugation and exposed in $100 \mu$ of culture medium to $3.7 \mathrm{kBq}$ of $\left[2{ }^{14} \mathrm{C}\right] 5 \mathrm{EtdUrd}$ (specific activity $133 \mathrm{MBq} / \mathrm{mmol}$ ) or $3.7 \mathrm{kBq}$ of [methyl $-{ }^{14} \mathrm{C}$ ] thymidine (specific activity $141 \mathrm{MBq} / \mathrm{mmol}$ ). The cells were washed twice with ice-cold PBS and the cell pellets were dissolved in $50 \mu \mathrm{l}$ of proteinase $\mathrm{K}$ solution (proteinase $\mathrm{K}, 2 \mathrm{mg} / \mathrm{ml}$; Tris- $\mathrm{HCl}$, pH 7.5, $50 \mathrm{mM}$; NaCl, $150 \mathrm{mM}$; EDTA, $2 \mathrm{mM}$; sodium dodecyl sulfate, $0.5 \%$ ) and incubated for $16 \mathrm{~h}$ at $37^{\circ} \mathrm{C}$. The nucleic acids were separated by four successive phenol extractions. The nucleic acids were then precipitated with ethanol and washed three times in order to remove phenol. RNA was hydrolyzed for $16 \mathrm{~h}$ at $37^{\circ} \mathrm{C}$ with $0.3 \mathrm{M} \mathrm{KOH}$. DNA was precipitated again with $70 \%$ ethanol. DNA was hydrolyzed with formic acid, $30 \mathrm{~min}$ at $175^{\circ} \mathrm{C}$ and the bases were separated chromatographically on cellulose plates (E. Merck): chromatography was carried out at room temperature $\left(20-24^{\circ} \mathrm{C}\right.$ ) in a glass chromatography tank with no pretreatment. $1 \mu \mathrm{l}$ of each base (see below) from a $50 \mathrm{mM}$ water solution stock, together with the sample aliquot, was applied to the lower left corner of the plate. The first ascending development was performed to 18-19 $\mathrm{cm}$ from the bottom with butanol-ammonia-water (86:4:10). The plate was dried with a blow drier and the development was repeated. A second ascending development in a 90 Acta Chem. Scand. B 39 (1985) No. 9 


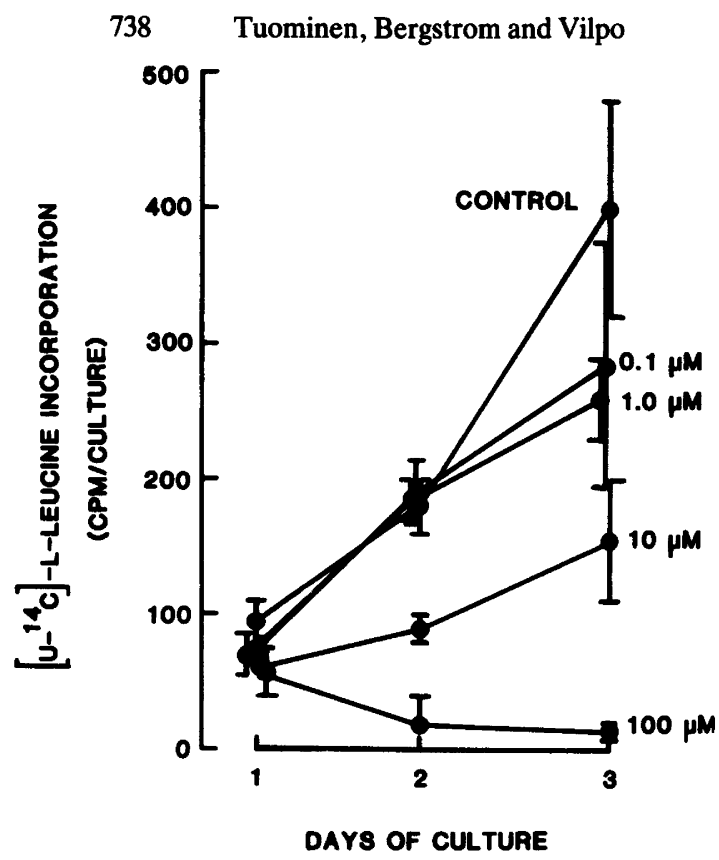

Fig. 1. Toxicity of 5EtdUrd studied daily in BALL-1 cell cultures. The cells were grown in microplate cultures initially containing 0 to $100 \mu \mathrm{M}$ 5EtdUrd. Radioactive leucine was added for the four final hours, after which the proteins were precipitated with perchloric acid. The precipitates were collected by a multiple cell harvester onto glass fiber filters and radioactivity was counted.

degree direction was performed with butanol-water (86:14). This step was also repeated. The marker molecules were localized under UV light, the spots were cut off and the radioactivity counted. Full separation of the following markers was obtained: adenine, cytosine, 5-ethyluracil, guanine, 5-hydroxymethylcytosine, 5-hydroxymethyluracil, 5methylcytosine, thymine and uracil.

\section{RESULTS}

Cytotoxicity tests. 5EtdUrd was toxic to all leukemic cell types when present at a $10 \mu \mathrm{M}$ concentration. An example of the manifestation of this toxic effect of 5EtdUrd is demonstrated in Fig. 1; the reduction of $\left[\mathrm{U}-{ }^{14} \mathrm{C}\right]$-L-leucine incorporation was not obvious over the first $24 \mathrm{~h}$ of culture but it manifested thereafter in a dose-dependent fashion as shown with BALL-1 cells in Fig. 1. Similar time/[U $\left.-{ }^{14} \mathrm{C}\right]-\mathrm{L}-$-leucine incorporation curves were obtained with all other leukemic cell lines assayed in this work (results not shown). The cytotoxicity of 5EtdUrd appeared to be independent of the leukemic cell type tested. A $60 \%$ or higher reduction in $\left[\mathrm{U}-{ }^{14} \mathrm{C}\right]$-L-leucine incorporation was achieved with $10 \mu \mathrm{M}$ 5EtdUrd, as shown in Table 1 . The corresponding growth inhibition by $100 \mu \mathrm{M}$ 5EtdUrd was $93-100 \%$. The inhibition of protein synthesis by 5EtdUrd in normal human peripheral blood PHA-stimulated lymphocytes was much weaker than that in leukemic cells (Table 1).

Incorporation of $\left[2{ }^{14} \mathrm{C}\right] 5 \mathrm{EtdUrd}$ into DNA. $\left[2-{ }^{14} \mathrm{C}\right] 5 \mathrm{EtdUrd}$ was incorporated into DNA of human peripheral blood PHA-stimulated lymhocytes, as illustrated in Fig. 2. The ratio of 5EtdUrd- to thymidine-incorporation was approximately 0.4 in spite of the great variation of proliferative activity of the cells at different times after the initiation of the cultures (Fig. 2). The radioactivity derived from $\left[2-{ }^{14} \mathrm{C}\right] 5 \mathrm{EtdU}$ rd was present in 5-ethyluracil and none was detected in guanine, adenine, cytosine or 5-hydroxymethyluracil, when purified DNA was hydrolyzed with formic acid and the bases analyzed by a two-dimensional thin-layer 


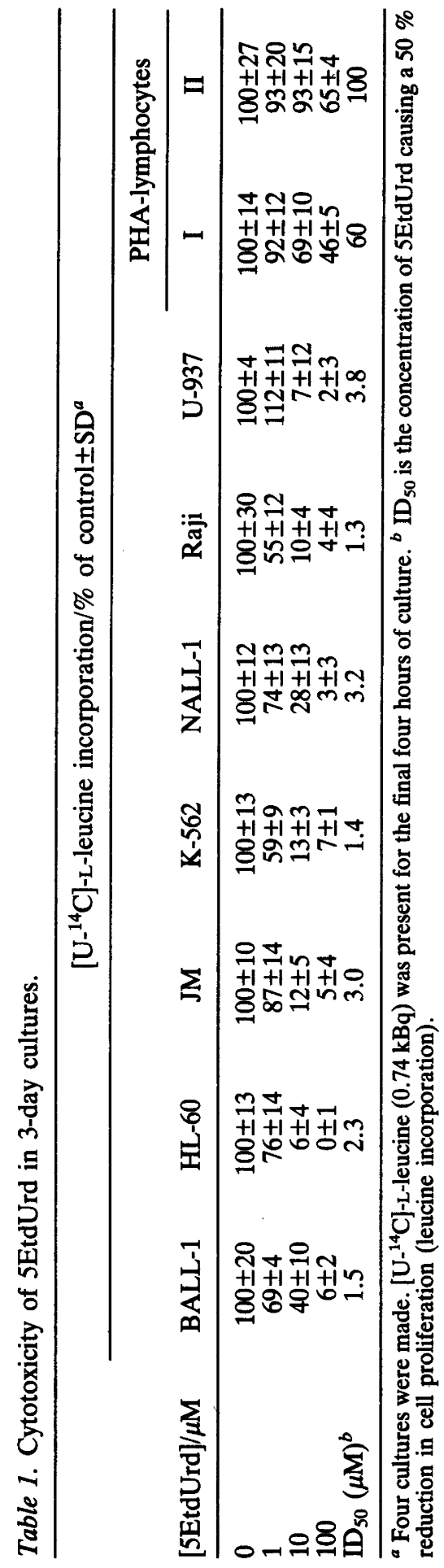

Acta Chem. Scand. B 39 (1985) No. 9 

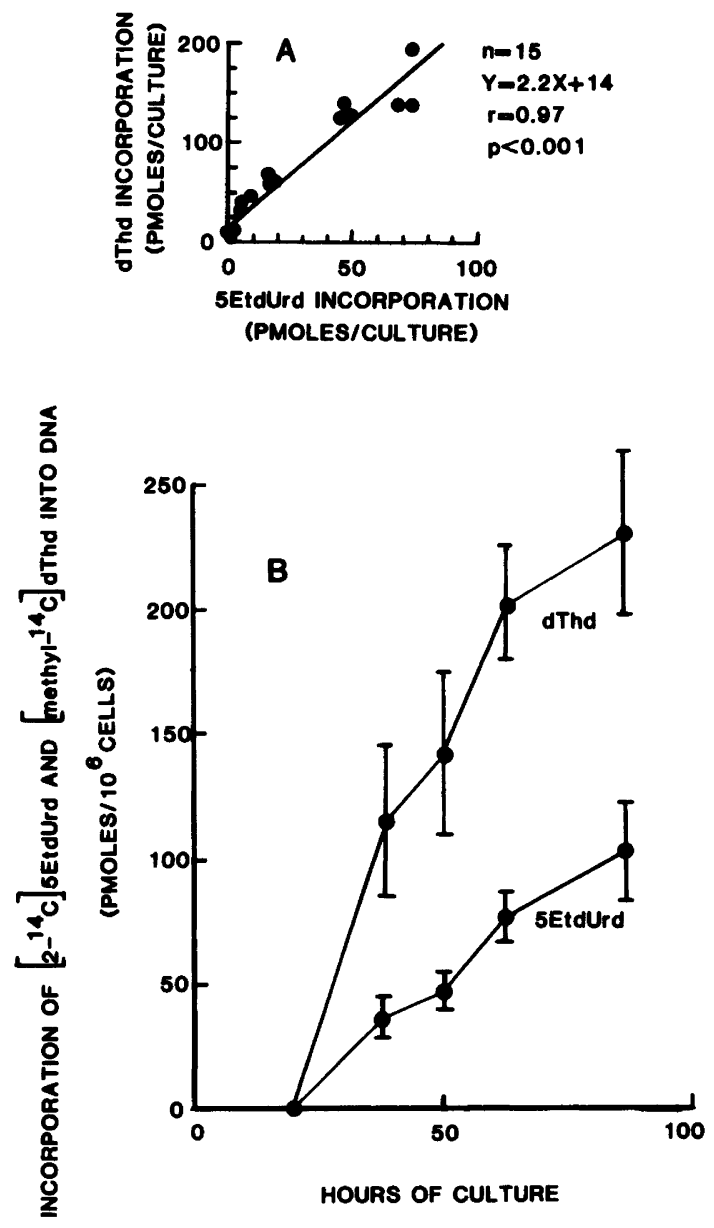

Fig. 2. Incorporation of $\left[2-{ }^{14} \mathrm{C}\right] 5 \mathrm{EtdUrd}$ - and [methyl $\left.-{ }^{14} \mathrm{C}\right]$ thymidine-derived radioactivity into the DNA of human peripheral blood PHA-stimulated lymphocytes. After various culture periods radioactive 5EtdUrd and thymidine were added to separate $1 \mathrm{ml}$ subcultures. After $60 \mathrm{~min}$ exposure the DNA was isolated by a modified Schmidt-Thannhauser procedure and the radioactivity was counted. (A) Correlation of thymidine (dThd)-derived incorporation analyzed by the least-squares regression method. (B) The same data as in (A) presented as progress of incorporation of 5EtdUrd- and thymidine-derived radioactivity during PHA-stimulation. Each point represents the mean $( \pm S D)$ of three cultures.

chromatography. Some radioactivity, however, co-migrated with thymine (Table 2). Most of the radioactivity in isolated DNA from $\left[2-{ }^{14} \mathrm{C}\right] 5 \mathrm{EtdUrd}$-exposed leukemic JM cells was also in 5-ethyluracil. This was demonstrated by two-dimensional thin-layer chromatography (results not shown), as for PHA-stimulated peripheral blood lymphocytes.

$\left[2-{ }^{14} \mathrm{C}\right] 5 \mathrm{EtdU}$ rd incorporation was also demonstrated in 3-day cultures of human leukemic cell lines BALL-1 and Raji. Increasing concentrations of 5EtdUrd tended to increase the proportion of radioactivity in the acid-soluble fraction, as illustrated in Table 3. 
Table 2. Radioactivity in individual DNA-bases of human peripheral blood PHA-stimulated lymphocytes exposed for $60 \mathrm{~min}$ to $\left[{ }^{14} \mathrm{C}\right]$-labeled 5EtdUrd and thymidine. The background activity (not subtracted) was $20 \pm 3 \mathrm{cpm}$.

\begin{tabular}{lcc}
\hline & \multicolumn{2}{c}{ Radioactivity $\left(\mathrm{cpm} / 5 \times 10^{7}\right.$ cells $)$} \\
\cline { 2 - 3 } Base & {$\left[2-{ }^{14} \mathrm{C}\right] 5$ EtdUrd } & {$\left[\right.$ methyl- ${ }^{14}$ C]thymidine } \\
\hline Guanine & 26 & 33 \\
Cytosine & 20 & 18 \\
5-Hydroxymethyluracil & 20 & 18 \\
Uracil & 20 & 15 \\
Adenine & 21 & 22 \\
Thymine & 40 & 393 \\
5-Ethyluracil & 406 & 19 \\
\hline
\end{tabular}

Table 3. Incorporation of $\left[2-{ }^{14} \mathrm{C}\right] 5 \mathrm{EtdU}$ rd in BALL-1 and Raji cells in 3-day cultures.

\begin{tabular}{|c|c|c|c|c|}
\hline \multirow[b]{3}{*}{ Fraction } & \multicolumn{4}{|c|}{ Incorporation $\left(\mathrm{pmol} / 10^{6} \text { cells } \pm \mathrm{SD}\right)^{a}$} \\
\hline & \multicolumn{2}{|c|}{ BALL-1 } & \multicolumn{2}{|r|}{ Raji } \\
\hline & 5 EtdUrd $/ 25 \mu \mathrm{M}$ & $5 E t d U r d / 100 \mu \mathrm{M}$ & 5EtdUrd/25 $\mu \mathrm{M}$ & $5 \mathrm{EtdUrd} / 100 \mu \mathrm{M}$ \\
\hline $\begin{array}{l}\text { Acid sol. } \\
\text { DNA }\end{array}$ & $\begin{array}{c}58 \pm 13 \\
574 \pm 122\end{array}$ & $\begin{array}{l}1294 \pm 529 \\
3823 \pm 647\end{array}$ & $\begin{array}{c}780 \pm 99 \\
1436 \pm 254\end{array}$ & $\begin{array}{l}8704 \pm 2206 \\
5815 \pm 1700\end{array}$ \\
\hline
\end{tabular}

a Three cultures were analyzed. Under identical culture conditions in microplates $25 \mu \mathrm{M} 5 \mathrm{EtdUrd}$ decreased the cell harvest by $19 \%$ in BALL-1 cell cultures and by $43 \%$ in Raji cell cultures, and 100 $\mu \mathrm{M} 5$ 5tdUrd decreased the harvest by 83 and by $82 \%$ in BALL-1 cell and Raji cell cultures, respectively. $25 \mu \mathrm{M} 5$ EtdUrd corresponded to $0.74 \mathrm{kBq}$ and $200 \mu \mathrm{M} 5$ EtdUrd to $2.96 \mathrm{kBq}$.

\section{DISCUSSION}

A simplified procedure for preparation of 5EtdUrd on a microscale was developed for the purpose of obtaining radiolabeled material. Unlike the original large scale procedure described by Bergstrom and Ogawa, ${ }^{11}$ the present procedure is done in a single flask without isolation of either intermediate. $\left[2-{ }^{14} \mathrm{C}\right]-2^{\prime}$-deoxyuridine ( 1 in Scheme 1$)$ and mercury(II)acetate react in aqueous solution to give the 5-mercuri derivative, $2^{23}$. Reaction of 2 with $\mathrm{Li}_{2} \mathrm{PdCl}_{4}$ and ethene in methanol gives 5-methoxyethyl-2'-deoxyuridine (3). ${ }^{11}$ Nucleoside 3 was not isolated, but immediately subjected to hydrogenolysis $\left(\mathrm{H}_{2}, \mathrm{Pd} / \mathrm{C}\right)$ to remove the methoxy group, giving 5-ethyl-2'-deoxyuridine (4). This chemistry has been discussed elsewhere ${ }^{11}$ but was not previously accomplished in a singleflask procedure as described here.

The toxicity of 5EtdUrd has been demonstrated in various organisms such as viruses, bacteria and mammalian cells in vitro. The present investigation extends the data to most variants of human acute leukemia; 5EtdUrd was predictably toxic to all leukemia cell lines tested. The variability in the response between the lines was minimal. Namely, the doses inhibiting the protein synthesis of the culture by $50 \%$ compared with the cultures without 5 EtdUrd were within the range of 1.3 to $3.8 \mu \mathrm{M}$. Comparable ID $_{50}$ concentrations for mouse leukemia $\mathrm{L} 1210^{24}$ and human lymphoblasts ${ }^{25}$ have been approximately ten times higher, or

Acta Chem. Scand. B 39 (1985) No. 9 


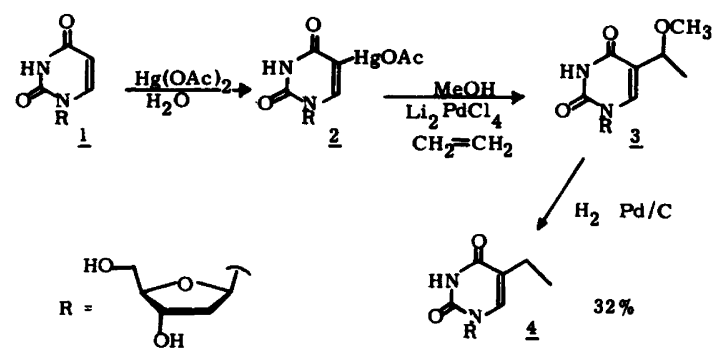

Scheme 1.

$33 \mu \mathrm{M}$ and $38 \mu \mathrm{M}$, respectively. Considerable differences, however, can be observed in different sublines from the same origin, as in the case of Raji cells. The $\mathrm{ID}_{50}$ for Raji cells observed by De Clercq and coworkers ${ }^{25}$ was $19.9 \mu \mathrm{g} / \mathrm{ml}(78 \mu \mathrm{M})$ and our value was $1.3 \mu \mathrm{M}$. The difference could be based on the thymidine kinase activity; low activities make cells more resistant to 5 EtdUrd. ${ }^{25}$

The cytotoxicity of 5EtdUrd as measured by leucine incorporation was manifested after the first day of culture. This means that the compound does not immediately reduce the protein synthesis of leukemic cells. This experimental finding supports the predictable mechanism of action of 5EtdUrd as a thymidine antimetabolite.

A remarkable difference in the susceptibility to 5EtdUrd was demonstrated between normal and malignant T cells. Although the $\mathrm{ID}_{50}$ for $\mathrm{JM}$ was $3.0 \mu \mathrm{M}$, the $\mathrm{ID}_{50}$ for human PHA-stimulated lymphocytes approached or even exceeded $100 \mu \mathrm{M}$. The resistance of immunoreactive cells to 5 EtdUrd has been reported in mice: $200 \mathrm{mg} / \mathrm{kg} /$ day given intraperitoneally for six days did not suppress the primary immunoresponse to an intravenous injection of sheep red cells. ${ }^{26}$ This lack of effect, however, could possibly be accounted for by the rapid elimination of 5EtdUrd in vivo (cf. Ref. 7.). The relative resistance to 5EtdUrd of cultured human lymhocytes has also been observed when the cells were exposed to $100 \mu \mathrm{g}$ of $5 \mathrm{EtdUrd}$ per $\mathrm{ml}(390 \mu \mathrm{M})$ and no chromosomal aberrations were seen. $^{6}$

It has been shown previously that 5EtdUrd-derived radioactivity is incorporated into the DNA of mammalian cells. ${ }^{6-8}$ We have demonstrated for the first time that 5EtdUrd-derived radioactivity of isolated DNA-hydrolysate co-chromatographed mainly with 5-ethyluracil, although some radioactivity was also present in thymine. The possible thymidine contamination in the original $\left[2-{ }^{14} \mathrm{C}\right] 5 \mathrm{EtdU}$ rd preparation was less than $1 \%$. It remains to be clarified whether 5EtdUrd can be metabolized to thymidine.

Experimental chemotherapy with 5EtdUrd has been hampered by the rapid elimination of the compound in vivo. ${ }^{7} \mathrm{~A}$ catabolic enzyme, thymidine phosphorylase, is present in normal human tissues. ${ }^{27}$ Nevertheless, virostatic concentrations of 5 EtdUrd can be achieved in rodents ${ }^{28}$ and according to our preliminary observations, the catabolism of 5EtdUrd in human blood is relatively slow (Vilpo, unpublished results). The final value of 5EtdUrd against human leukemia in vivo, alone or in combinations with other therapeutic agents, remains to be evaluated.

Acknowledgements. We thank Mrs. Leena Vilpo for technical assistance. This investigation was supported by grant No. CA 30050 awarded by the National Cancer Institute, U.S.A. (D.E.B.) and by a grant from the Finnish Foundation for Cancer Research (J.A.V.). 


\section{REFERENCES}

1. Pietrzykowska, F. and Shugar, D. Biochem. Biophys. Res. Commun. 25 (1966) 567.

2. Pietrzykowska, F. and Shugar, D. Acta Biochim. Pol. 14 (1967) 169.

3. De Clercq, E. and Shugar, D. Biochem. Pharmacol. 24 (1975) 1073.

4. Walter, R.D. and Gauri, K.K. Biochem. Pharmacol. 24 (1975) 1025.

5. Piechowska, M. and Shugar, D. Biochem. Biophys. Res. Commun. 20 (1965) 768.

6. Singh, S., Willers, I. and Goedde, H.W. Hum. Genet. 24 (1974) 135.

7. Silagi, S., Balint, R.F. and Gauri, K.K. Cancer Res. 37 (1977) 3367.

8. Swierkowska, K.M., Jasińska, J.K. and Steffen, J.A. Biochem. Pharmacol. 22 (1973) 85.

9. Vilpo, J.A., Jekunen, A., Vilpo, L. and Bergstrom, D. 3rd International Symposium of Therapy of Acute Leukemias Officine Grafishe della Pacini Editory, Pisa, Italy 1982, p. 458.

10. Barefield, E.K. J. Chem. Educ. 50 (1973) 697.

11. Bergstrom, D.E. and Ogawa, M.K. J. Am. Chem. Soc. 100 (1978) 8106.

12. Miyoshi, I., Hiraki, S., Tsubota, T., Kubonishi, I., Matsuda, Y., Nakayama, T., Kishimoto, N. and Kimura, I. Nature 267 (1977) 843.

13. Collins, S.J., Gallo, R.C. and Gallagher, R.E. Nature 270 (1977) 347.

14. Schwenk, H.-U. and Schneider, U. Blut 31 (1975) 299.

15. Lozzio, C.B. and Lozzio, B.B. Blood 45 (1975) 321.

16. Pulvertaft, R.J.V. Lancet 1 (1964) 238.

17. Sundström, C. and Nilsson, K. Int. J. Cancer 17 (1976) 565.

18. Böyum, A. Scand. J. Clin. Lab. Invest. 21 (1968) 77.

19. Chen, T.R. Exp. Cell Res. 104 (1977) 255.

20. Kahilainen, L.I., Bergstrom, D.E. and Vilpo, J.A. Acta Chem. Scand. B 39 (1985) 477.

21. Mishell, B.B., Shiigi, S.M., Henry, C., Chan, E.L., North, J., Gallily, R., Slomich, M., Miller, K., Marbrook, J., Parks, D. and Good, A.H. In Mishell, B.B. and Shiigi, S.M., Eds., Selected Methods in Cellular Immunology, Freeman, San Francisco 1983, p. 3.

22. Fleck, A. and Begg, D. Biochim. Biophys. Acta 108 (1965) 333.

23. Bergstrom, D.E. and Ruth, J.L. J. Carbohydrates Nucleosides Nucleotides 4 (1977) 257.

24. De Clercq, E., Balzarini, J., Torrence, P.F., Mertes, M.P., Schmidt, C.L., Shugar, D., Barr, P.J., Jones, A.S., Verhels, G. and Walker, R.T. Mol. Pharmacol. 19 (1981) 321.

25. Balzarini, J., De Clercq, E., Torrence, P.F., Mertes, M.P., Park, J.S., Schmidt, C.L., Shugar, D., Barr, P.J., Jones, A.S., Verhels, G. and Walker, R.T. Biochem. Pharmacol. 31 (1982) 1089.

26. Gauri, K.K., Malorny, G. and Schiff, W. Chemotherapy 14 (1969) 129.

27. Desgranges, C., Razaka, G., Rabaud, M., Bricaud, H., Balzarini, J. and De Clercq, E. Biochem. Pharmacol. 32 (1983) 3583.

28. Davis, W.B., Oakes, J.E. and Taylor, J.A. Antimicrob. Agents Chemother 14 (1978) 743.

Received January 18, 1985. 